\title{
Frequency of ophthalmological posterior segment findings in patients with inflammatory bowel disease
}

\author{
Luis Filipe NAKAYAMA ${ }^{1}$, Vinicius Campos BERGAMO ${ }^{1}$, Marina Lourenço de CONTI ${ }^{1}$, Lívia de Almeida COSTA2 \\ Nilva Simeren Bueno de MORAES ${ }^{1}$ and Orlando AMBROGINI JR ${ }^{2}$
}

Received 16/12/2017 Accepted 12/3/2018

\begin{abstract}
Background - Inflammatory bowel disease is a systemic inflammatory disease classified as Crohn disease or ulcerative colitis. It could present extra intestinal findings, such as fever, weight loss, arthralgia, mucocutaneous lesions, hepatic, renal and ophthalmological involvement. Among ophthalmological findings, posterior segment findings are present in less than $1 \%$ of patients with inflammatory bowel disease, however, these findings could bring definitive visual impairment. Objective - Our study objective was to evaluate ocular posterior segment findings is patients with inflammatory bowel disease, through retinal mapping, color fundus retinography, optical coherence tomography (OCT) and OCT angiography, and compare our results to literature. Methods - We evaluated eighty patients with inflammatory bowel disease through complete ophthalmological examination and posterior segment assessment. Color fundus retinography, OCT and OCT angiography was performed with Topcon Triton (Topcon ${ }^{\circledR}$, Tokyo, Japan). Macula and posterior pole were evaluated with binocular indirect ophthalmoscopy and fundus biomicroscopy. Results - Participants mean age was 44.16 years (18.08-68.58), 28 (35\%) male patients and 52 (65\%) female patients. Thirty-five (44\%) with diagnosis of Crohn disease, $41(52 \%)$ patients with diagnosis of ulcerative colitis and $3(4 \%)$ had non-conclusive Crohn disease or ulcerative colitis classification. We found abnormal exams in $21(26.25 \%)$ patients. Conclusion - Our study found similar prevalence of ophthalmological posterior segment commitment compared to previous literature prevalence. The findings were predominantly unrelated to inflammatory bowel disease, rather than primarily related to it. The most prevalent, and non-previous reported, finding was increased arteriolar tortuosity, probably occurs due to systemic vascular impairment in inflammatory bowel disease.
\end{abstract}

HEADINGS - Inflammatory bowel diseases, complications. Retina, pathology. Optical coherence tomography.

\section{INTRODUCTION}

Inflammatory bowel disease (IBD) is a systemic inflammatory condition that can be classified as Crohn disease (CD) or ulcerative colitis (UC). In CD occurs transmural inflammation that may affect any segment of the gastrointestinal tract and in UC occurs mucosal inflammation, usually limited to the colon ${ }^{(1)}$.

Inflammatory bowel diseases are immune-mediated disorders that affects 1.5 millions of Americans and 2.2 millions of Europeans, with significant increase of its incidence in last decade ${ }^{(2)}$.

Lack of data register and healthy system access make it difficult to determine the exact Brazilian prevalence of $\mathrm{IBD}^{(3)}$.

It has an incidence peak between life's second and forth decade. Living in an urban area is a major risk factor, as well as living at north latitudes and some ethnicities, such as Jewish ${ }^{(2)}$.

Smoking, sedentarism, obesity, low dietary fiber ingestion, use of non-steroidal inflammatory drugs, menopause hormone therapy and precarious hygiene conditions also contribute to IBD pathogenesis $^{(2)}$.
The exact IBD pathophysiology is yet unknown and comprise a complex interaction of genetic, environmental, psychological, microbiological and immunological factors.

Extra intestinal IBD impairment involves hepatobiliary, renal, ophthalmological systems, and could present also general symptoms such as fever, weight loss, arthralgia and mucocutaneous lesions. These are the first IBD symptoms in $10 \%-20 \%$ of cases $^{(4)}$.

Extra intestinal IBD proposed pathogenesis are a combination of allergic and immune reactions, that create immune complexes composed by antigen and antibody, which deposits in extra intestinal tissues ${ }^{(5)}$.

Ophthalmological impairment is present in about $3.5 \%$ to $12 \%$ of IBD patients ${ }^{(6-9)}$, and isn't directly correlated to intestinal mucocutaneous extension, usually occurs in IBD early years ${ }^{(8)}$.

Possible ophthalmological findings are periocular edema, blepharitis, proptosis, conjunctivitis, scleritis, episcleritis, keratopathy, cataract, optic neuritis, optic, neuropathy, iridociclitis, retinal pigment epithelial atrophy, macular edema, serous retinal detachment and retinal hemorrhages ${ }^{(3,10)}$.

${ }^{1}$ Universidade Federal de São Paulo, Escola Paulista de Medicina, Departamento de Oftalmologia e Ciências Visuais, São Paulo, SP, Brasil. ${ }^{2}$ Universidade Federal de São Paulo, Escola

Paulista de Medicina, Departamento de Gastroenterologia, São Paulo, SP, Brasil.

Corresponding author: Luis Filipe Nakayama. E-mail: nakayama.luis@gmail.com 
Episcleritis is the most frequent ophthalmological finding and it's responsible for $29 \%$ of ocular involvement, followed by scleritis, responsible for $18 \%$, and uveitis, responsible for $17 \% \%^{(6,10,11)}$.

Ophthalmological involvement can be classified as primary or directly related to IBD, which could improve after immunosuppression therapy, secondary or consequent to primary commitment, and coincidental findings, that can occur in general population and do not have direct correlation to IBD or its treatment ${ }^{(6,10)}$.

Ophthalmological posterior segment findings exact prevalence is controversial. Yilmaz et at, in a group of one hundred and sixteen patients, did not found any retinal, uveal or choroidal findings, while Felekis et at., with sixty patients, found $30.8 \%$ of posterior segment findings, otherwise with another methodology and fewer patients number compared to Yilmaz. Posterior segment finding are very relevant because they can lead to irreversible blindness.

Our study objective was to evaluate ophthalmological posterior segment findings prevalence through eye fundus exam, colored retinography, Optical Coherence Tomography (OCT) and OCT Angiography, and to compare our results to previous literature findings.

\section{METHODS}

This was a cross-sectional study of eighty patients from the Gastroenterology outpatient clinic of Escola Paulista de Medicina / UNIFESP with IBD diagnosis.

The study was approved in UNIFESP Ethics Committee (CAAE 61285216.0.0000.5505) and all patients were informed about ophthalmological exams and procedures and signed consensual informed participation term.

They underwent complete ophthalmological examination at same period of day and by the same evaluator. It consisted of Snellen visual acuity measurement with best refractive correction, automatic refraction with Nidek ARK 1 (Nidek, Japan) and spheric equivalent analysis, slit lamp exam of anterior segment, intraocular pressure measurement with Goldmann tonometer, superficial surface evaluation with lisamine green and tear break up time, and fundus examination was performed after pupil dilation with indirect binocular ophthalmoscope. Posterior segment exams were performed with Swept-Source Optic Coherence Tomography Triton (Topcon ${ }^{\circledR}$, Tokyo, Japan). All patients went through color funds retinography, horizontal foveal OCT line, vertical foveal OCT line, macular $3 \times 3 \mathrm{~mm}$ OCT, 3x3 $\mathrm{mm}$ and 6x6 mm macular Angiography OCT in right and left eyes.

Posterior segment findings were evaluated by two independent ophthalmologists through colored funds retinography, OCT and OCT Angiography analysis. The examiners were blind to patient diagnosis, age, treatment and other examiner findings.

\section{RESULTS}

A total of eighty patients were enrolled in the study. The participants mean age was 44.16 years (maximum of 68 years and 7 months; and minimum of 18 years and 1 month). Twenty-eight participants were male $(35 \%)$ and fifty-two were female $(65 \%)$.

Thirty-five patients (44\%) with diagnosis of Crohn disease, $41(52 \%)$ with ulcerative retocolitis diagnosis and three had nonconclusive CD or UC classification (4\%).

Among posterior pole evaluation, twenty-one patients had positive findings that correspond to $26.25 \%$ of total cases and fifty-nine had normal fundus exam. (FIGURE 1)

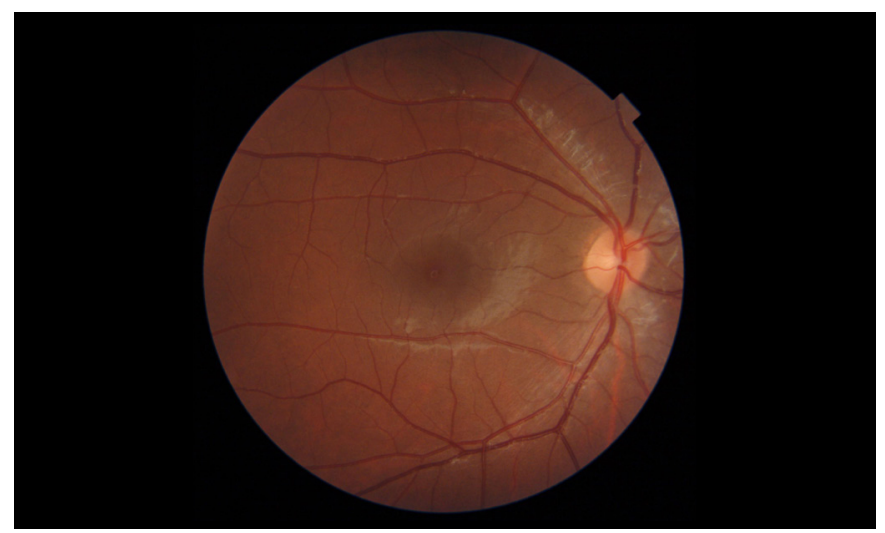

FIGURE 1. Normal fundoscopy. Pink optic disc with sharp margins, normal vessels and macula, attached retina.

Isolated arteriolar tortuosity was observed in eleven patients $(13.75 \%)$, with mean age of 37.03 years, with maximum of 59.25 years and minimum 18.8 years. (FIGURE 2)

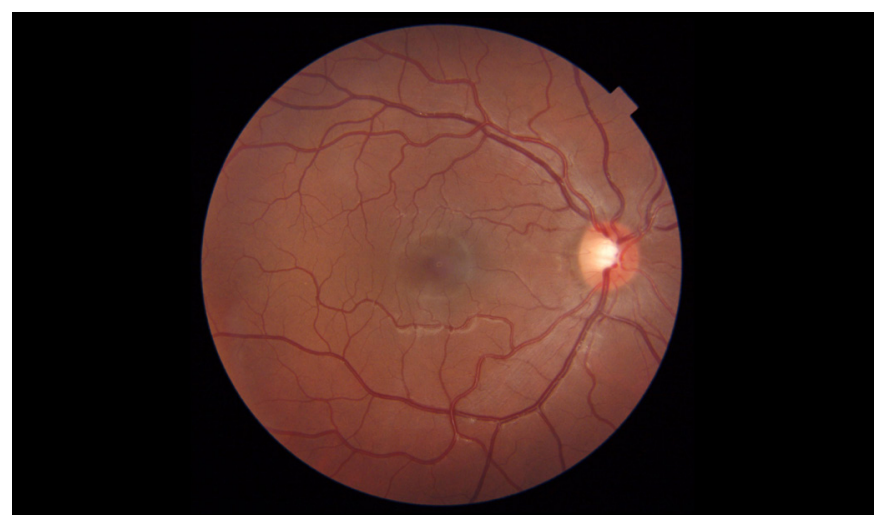

FIGURE 2. Only arteriolar tortuosity. Pink optic disc with sharp margins, increased arteriolar tortuosity and normal veins, attached retina.

Hard drusen were found in six patients $(7.5 \%)$, with mean age of 61.34 years, maximum of 68.58 and minimum of 50.75 years.

Both arterial and venous tortuosity were found in three patients (3.7\%), with mean age of 52.33 years, maximum of 63.5 and minimum of 40.5 years. (FIGURE 3)

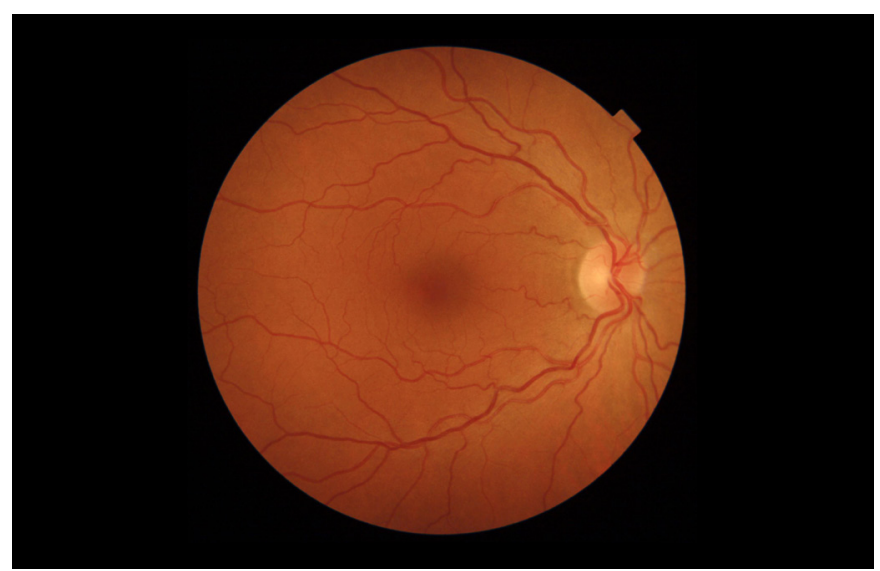

FIGURE 3. Diffuse vascular tortuosity. Pink optic disc with sharp margins, increased arteriolar and venular tortuosity, attached retina. 
It was found one unspecific papillomacular bundle subretinal alteration in one patient, with 35 years and no background history.

All drusen findings were confirmed by Optical Coherence Tomography, as subretinal lesions with hyper reflective material between Bruch membrane and retinal pigmented epithelium.

All patients with isolated arterial tortuosity did not presented systemic arterial hypertension at the moment of evaluation or use of antihypertensive treatment.

One of three patients with both venous and arteriolar tortuosity presented systemic arterial hypertension treated and controlled at the moment of evaluation.

Body mass index (BMI) values, mean value, systolic and diastolic arterial pressure, using drugs and disease activity from arterial and vascular tortuosity groups are compiled in TABLE 1 and TABLE 2.

\section{DISCUSSION}

The proposed methodology was similar to previous studies that evaluated retinal fundoscopic findings in patients with IBD, through general ophthalmological exam and colored retinography analysis. The great differential of this study is the use of SweptSource Optical Coherence Tomography and OCT Angiography as assistance as ancillary exams.

Previous Brazilian studies also do not distinguish between anterior and posterior ocular findings and one previous cross-sectional study reports prevalence of $6.2 \%$ in all ophthalmological findings ${ }^{(12)}$.

We found a higher incidence of ophthalmological fundoscopy findings in evaluated patients comparing to previous studies ${ }^{(6-10)}$. Felekis et al. also found similar high prevalence of posterior segment findings, but with no differentiation between primary, secondary or coincidental findings.
Our main finding was a high prevalence of vascular changes, with isolated increase of arteriolar tortuosity.

Drusen findings observed was probably secondary to age related physiologic degeneration, but with no signs of Age Macular Degeneration complications, such as choroidal neovascularization, retinal atrophy or soft drusen.

These findings corroborate with Felekis et al. study, and demonstrate that the main posterior segment change at IBD patients was coincident or secondary findings, with few primary, direct correlated to IBD, findings.

Posterior segment findings, although rare, may lead to high morbidity due to irreversible vision loss.

Our study is the first to describe those vascular, mainly arteriolar, changes in IBD patients, probably due to systemic vascular involvement. However, more studies are necessary to establish a more accurate relation between vascular tortuosity changes and intestinal inflammatory disease, establish if it could be a method to grade IBD severity or activity and also check if other microvasculature systems also present the same vascular architecture changes.

\section{ACKNOWLEDGMENT}

We'd like to thank the Ophthalmology and Gastroenterology departments of Escola Paulista de Medicina / UNIFESP. We also would like to thank the research team Nikoly Tigani Fares, Mariana Batista and Bruno Queiroz Alves.

\section{Authors' contribution}

Nakayama LF: corresponding author, concept, writing. Bergamo VC: writing. Conti ML: writing. Costa LA: main project researcher, coordinator. Moraes NSB: review article. Ambrogini Jr O: review article.

TABLE 1. Arterial tortuosity group: age, BMI, systolic and diastolic arterial pressure, drugs in use and disease activity.

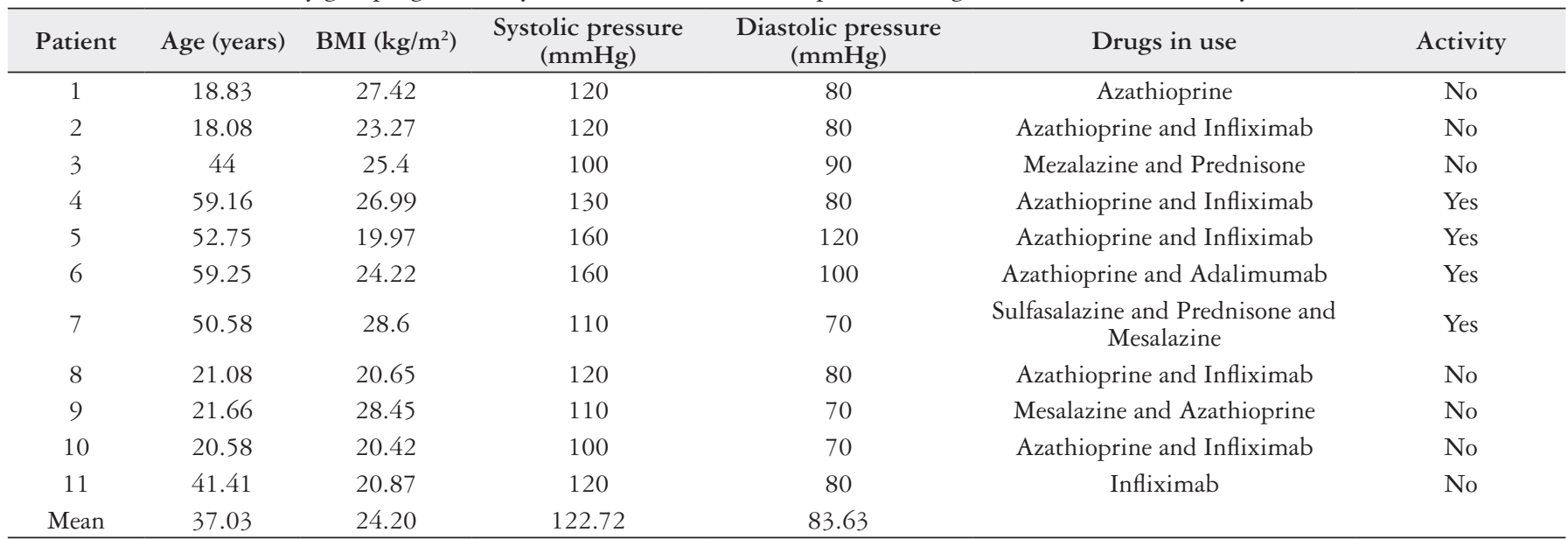

TABLE 2. Arterial and venular tortuosity group: age, BMI, systolic and diastolic arterial pressure, drugs in use and disease activity.

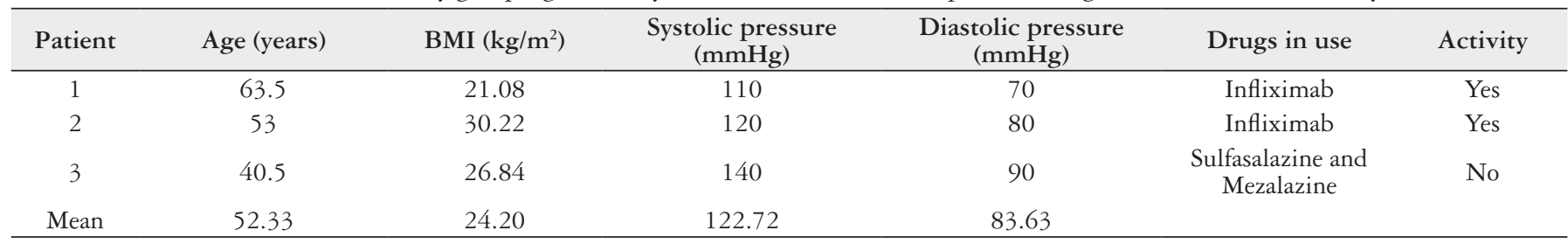


Nakayama LF, Bergamo VC, Conti ML, Costa LA, Moraes NSB, Ambrogini Jr O. Frequência de achados oftalmológicos de segmento posterior em pacientes com doença inflamatória intestinal. Arq Gastroenterol. 2018;55(2):188-91.

RESUMO - Contexto - As doenças inflamatórias intestinais são doenças inflamatórias sistêmicas que podem ser divididas em doença de Crohn ou retocolite ulcerativa. Além do quadro intestinal, elas podem apresentar sintomas extra intestinais como febre, perda de peso, artralgia, lesões mucocutâneas, acometimento hepatobiliar, acometimento renal e oftalmológico. Entre os achados oftalmológicos descritos, alterações de segmentos posterior são encontrados em menos de $1 \%$ dos pacientes com doença inflamatória intestinal, porém, tais achados podem levar à baixa acuidade visual definitiva. Objetivo - O objetivo do nosso trabalho foi avaliar alterações em segmento posterior através de retinografia colorida, mapeamento de retina, tomografia de coerência óptica e OCT angiography e comparar nossos resultados com o da literatura. Métodos - Foram avaliados 80 pacientes com doença inflamatória intestinal. Todos os pacientes foram submetidos a exame oftalmológico completo e a avaliação do segmento posterior. Foi realizada tomografia de coerência óptica em aparelho Triton (Topcon, Tokyo, Japan), retinografia colorida e OCT angiography. Mácula e polo posterior foram avaliados através de oftalmoscopia binocular indireta e biomicroscopia de fundo. Resultados - Entre os participantes, a média de idade foi de 44,16 anos (18,08-68,58), 28 (35\%) participantes do sexo masculino e 52 (65\%) do sexo feminino. Trinta e cinco (44\%) pacientes com diagnóstico de doença de Crohn, 41 (52\%) pacientes com diagnóstico de retocolite ulcerativa e $3(4 \%)$ pacientes em que não era possível classificar como doença de Crohn ou retocolite ulcerativa. Entre as avaliações de polo posterior, foram encontrados achados em exame de 21 pacientes, o que corresponde a 26,25\% dos casos. Conclusão - Nosso estudo encontrou resultados de prevalência de achados em exame de segmento posterior semelhante aos estudos prévios da literatura. Os achados foram de forma predominante não primariamente relacionados à doença inflamatória intestinal. O achado mais prevalente, e não previamente reportado, foi aumento de tortuosidade arteriolar, que provavelmente ocorre por envolvimento vascular sistêmico nas doenças inflamatórias intestinais.

DESCRITORES - Doenças inflamatórias intestinais, complicações. Retina, patologia. Tomografia de coerência óptica.

\section{REFERENCES}

1. Zhang Y-Z, Li Y-Y. Inflammatory bowel disease: Pathogenesis. World J Gastroenterol. 2014;20:91-9.

2. Ananthakrishnan AN. Epidemiology and risk factors for IBD. Nat Rev Gastroenterol Hepatol. 2015;12:205-17.

3. Souza MHLP, Troncon LEA, Rodrigues CM, Viana CFG, Onofre PHC, Monteiro RA, et al. Trends in the occurrence (1980-1999) and clinical features of Crohn's disease and ulcerative colitis in a university hospital in southeastern Brazil. Arq Gastroenterol. 2002;39:98-105.

4. Bernstein CN, Blanchard JF, Rawsthorne P, Yu N. The prevalence of extraintestinal diseases in inflammatory bowel disease: a population-based study. Am J Gastroenterol. 2001;96:1116-22.

5. Yilmaz S, Aydemir E, Madem A, Unsal B. The prevalence of ocular involvement in patients with inflammatory bowel disease. Int J Colorectal Dis. 2007;22:1027-30.

6. Ghanchi FD, Rembacken BJ. Inflammatory bowel disease and the eye. Surv Ophthalmol. 2003;48:663-76.

7. Knox DL, Schachat AP, Mustonen E. Primary, secondary and coincidental ocular complications of Crohn's disease. Ophthalmology. 1984;91:163-73.
8. Rankin GB, Watts HD, Melnyk CS, Kelley ML Jr. National cooperative Crohn's disease study: extraintestinal manifestations and perianal complications. Gastroenterology. 1979;77:914-20.

9. Greenstein AJ, Janowitz HD, Sachar DB. The extraintestinal complications of Crohn's disease and ulcerative colitis. Medicine. 1976;55:401-12.

10. Felekis T, Katsanos K, Kitsanou M, Trakos N, Theopistos V, Christodoulou D, et al. Spectrum and frequency of ophthalmologic manifestations in patients with inflammatory bowel disease: a prospective single-center study. Inflamm Bowel Dis. 2009; 15:29-34.

11. Thomas AS, Lin P. Ocular manifestations of inflammatory bowel disease. Curr Opin Ophthalmol. 2016;27:552-60.

12. Lanna CC, Ferrari M de L, Rocha SL, Nascimento E, de Carvalho MA, da Cunha AS. A cross-sectional study of 130 Brazilian patients with Crohn's disease and ulcerative colitis: analysis of articular and ophthalmologic manifestations. Clin Rheumatol. 2008;27:503-9.

\section{ERRATA}

In article "Frequency of ophthalmological posterior segment findings in patients with inflammatory bowel disease" published in journal Arquivos de Gastroenterologia, 2018;55(2):188-91, on pages 188,189,190 and 191.

Which was read: Lívia Bueno

Read: Lívia de Almeida Costa

And

Which was read: Bueno L

Read: Costa LA

DOI: dx.doi.org/10.1590/S0004-2803.201800000-34 